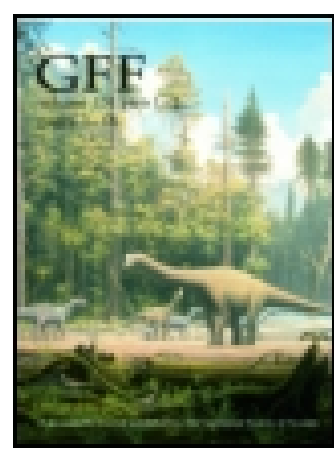

GFF

ISSN: 1103-5897 (Print) 2000-0863 (Online) Journal homepage: https://www.tandfonline.com/loi/sgff20

\title{
Detrital zircon record of the Mesoproterozoic to Lower Cambrian sequences of NW Russia: implications for the paleogeography of the Baltic interior
}

V.B. Ershova, A.S. Ivleva, V.N. Podkovyrov, A.K. Khudoley, P.V. Fedorov, D. Stockli, O. Anfindon, A.V. Maslov \& V. Khubanov

To cite this article: V.B. Ershova, A.S. Ivleva, V.N. Podkovyrov, A.K. Khudoley, P.V. Fedorov, D. Stockli, O. Anfindon, A.V. Maslov \& V. Khubanov (2019): Detrital zircon record of the Mesoproterozoic to Lower Cambrian sequences of NW Russia: implications for the paleogeography of the Baltic interior, GFF

To link to this article: https://doi.org/10.1080/11035897.2019.1625073

View supplementary material $\sqsubset \nearrow$

曲 Published online: 30 Sep 2019.

Submit your article to this journal ¿

Q View related articles $\sqsubset$

View Crossmark data 


\title{
Detrital zircon record of the Mesoproterozoic to Lower Cambrian sequences of NW Russia: implications for the paleogeography of the Baltic interior
}

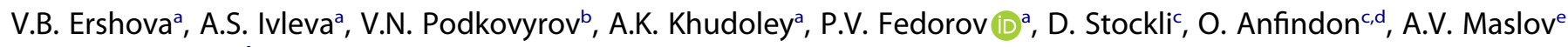 \\ and V. Khubanov \\ anstitute of Earth Sciences, Saint Petersburg State University, Saint Petersburg, Russia; 'blnstitute of Precambrian Geology and Geochronology, \\ Russian Academy of Science, St. Petersburg, Russia; ' Jackson School of Geoscience, University of Texas, Austin, TX, USA; dDepartment of Geology, \\ Sonoma State University, California, USA; 'Zavaritsky Institute of Geology and Geochemistry, Ural Branch of the Russian Academy of Sciences, \\ Ekaterinburg, Russia; ${ }^{f} G$ eological Institute, Siberian branch of Russian, Academy of Science, Ulan-Ude, Russia
}

\begin{abstract}
Laser ablation inductively coupled plasma mass spectrometry (LA-ICP-MS) U-Pb detrital zircon isotope data from Mesoproterozoic to Lower Cambrian strata of the St Petersburg region are used to characterize the paleogeographic and tectonic evolution of the Baltica continent. We dated fifteen samples and divided them into three groups based on their distribution of detrital zircons. The first group (comprising Lower Mesoproterozoic rocks) is dominated by Early Mesoproterozoic and Late Paleoproterozoic zircons, mostly derived from weathering of proximal source region including rapakivi granites exposed across the neighboring Baltic Shield. The second group includes Upper Ediacaran samples (Redkino and Kotlin Regional Stages), with major zircon populations ranging in age between 1970-1850 and 1600-1550 Ma, respectively, correlating with magmatic and metamorphic events within the Svecofennian Orogeny and rapakivi granite igneous activity in the interior of Fennoscandia. The third group of samples, collected from both the uppermost Ediacaran and lowermost Cambrian deposits (Kotlin, Lontova and Dominopol Regional Stages), contains older Paleo-Mesoproterozoic zircons as well as Late Neoproterozoic-earliest Cambrian zircons, indicating a Timanian source area and exhibiting a age spectra similar to spectra for coeval rocks of the Scandinavian Caledonides. Therefore, we conclude that reworking and transport of continental detritus from the Timanian Orogen began during Late Ediacaran, earlier than previously supposed, with transport of Timanian detritus not only to the marginal part of Baltica (known from the Scandinavian Caledonides), but also to the distal interior of Baltica.
\end{abstract}

\section{ARTICLE HISTORY}

Received 30 November 2018

Accepted 25 May 2019

\section{KEYWORDS}

Precambrian; Cambrian; Baltica; zircons; provenance; paleogeography

\section{Introduction}

The study region is located in northwest Russia (Leningrad District) and represents the interior part of the East European Platform, considered a discrete part of the Baltica paleocontinent during the Late Precambrian-Early Paleozoic, prior to accretion with Avalonia and Laurentia during the EarlyMiddle Paleozoic Caledonian Orogeny (Fig. 1). The clastic succession of the study area can offer a valuable insight into the latest Mesoproterozoic to Devonian geological history of the Baltica paleocontinent interior. Detrital zircon studies have emerged as a powerful tool for paleogeographic and tectonic reconstructions, allowing the source regions of clastic sedimentary rocks to be identified. However, whilst there are numerous provenance studies of Mesoproterozoic-Paleozoic successions of the Scandinavian Caledonides, which predominantly represented a marginal part of Baltica during the latest Precambrian-earliest Paleozoic (e.g., Andresen et al. 2014; Gee et al. 2014, 2015; Slama \& Pedersen 2015; Slama 2016; Zhang et al. 2015 and references therein), there are only few provenance studies of the clastic succession of the interior part of Baltica, occupied by the East European Platform. Previous work includes $\mathrm{U}-\mathrm{Pb}$ dating of detrital zircons from the Upper Mesoproterozoic succession of the Pasha-Ladoga basin (Kuptsova et al. 2011), a U-Pb detrital zircon study of Middle Cambrian-Devonian strata carried out by Miller et al. (2011), and the dating of several samples from EdiacaranDevonian strata from central Estonia (Isozaki et al. 2014; Poldvere et al. 2014). The only detrital zircon studies focused on the Leningrad region of the East European Platform in NW Russia are represented by recent preliminary studies published by Ivleva et al. (2016), Ivleva et al. (2018).

We present detrital zircon $\mathrm{U}-\mathrm{Pb}$ results from fifteen sandstone samples ranging from Mesoproterozoic to Early Cambrian in age, collected from the interior part of the East European Platform (Leningrad region), which shed new light on the Ediacaran- Early Cambrian paleogeographic evolution of the NW part of the Baltica paleocontinent (in present-day coordinates).

\section{Geological background}

The basement of the study region consists of highly metamorphosed Archean to Paleoproterozoic rocks (Bogdanova et al. 2008; Verbitskiy et al. 2012; Maksimov et al. 2015). The Mesoproterozoic-lowermost Cambrian sedimentary rocks are 

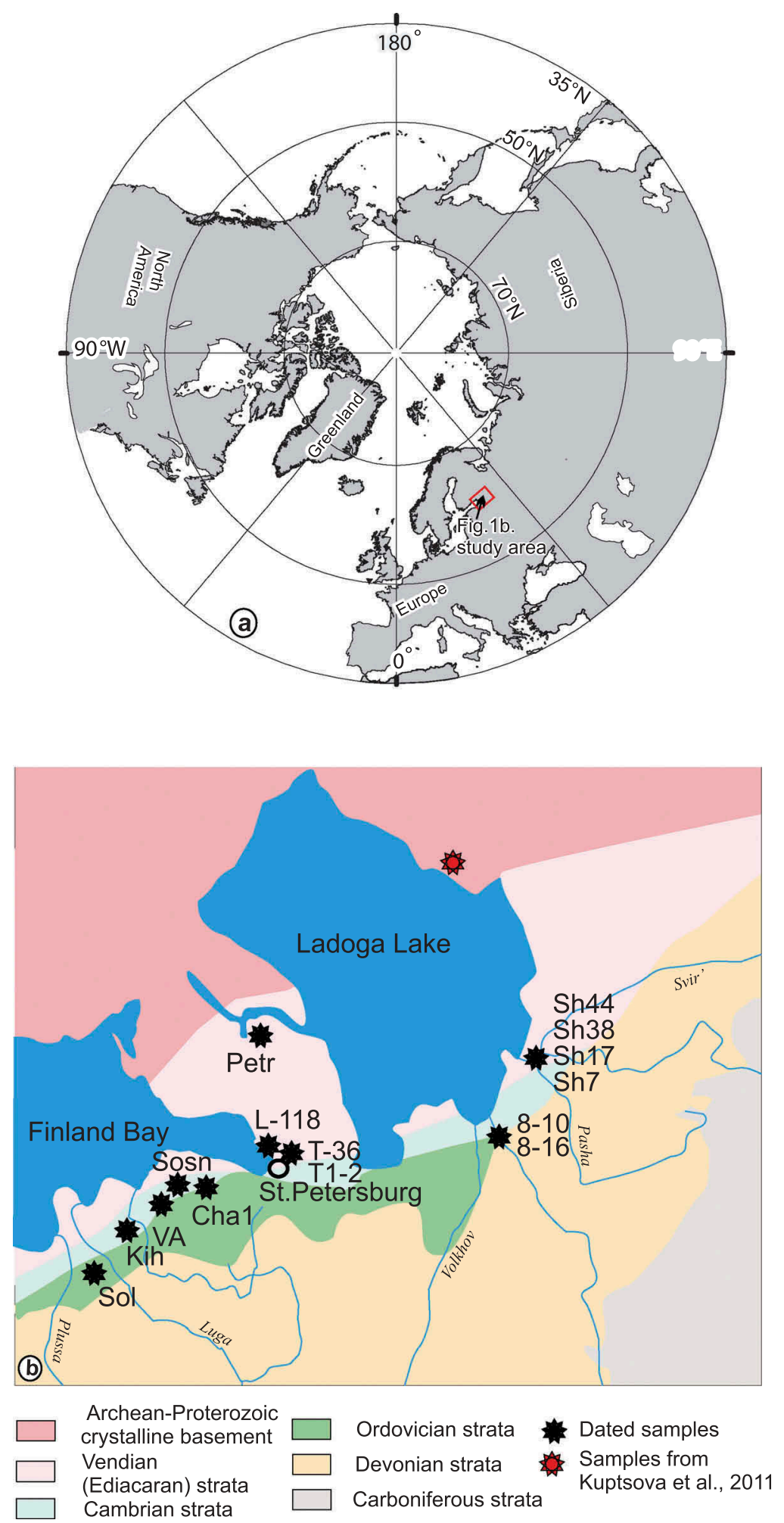

Figure 1. A. Regional setting of the study area. B. Sketch map of study region with location of dated samples.

mainly covered by younger Paleozoic and Quaternary overburden, although they crop out to the north in the Baltica-Ladoga Klint and are penetrated by several deep wells. The oldest sedimentary succession known from the study region is the Mesoproterozoic (Lower Riphean) sequence, which rests with a prominent angular unconformity on the Archean to Paleoproterozoic metamorphic basement and infills a distinct graben-like structure (the PashaLadoga graben) in the Ladoga Lake area (Kuptsova et al. 2011;
Maksimov et al. 2015). Mesoproterozoic rocks consist of texturally immature sandstones with conglomerate beds, comprising the Priozersk, Salmi and Pasha formations (Fig. 2). A few mafic lava flows and tuff beds are reported throughout the succession (Kuptsova et al. 2011). The thickness of the succession reaches up to $800 \mathrm{~m}$ in the center of the graben, decreasing to a few tens of meters towards the flanks. The youngest rocks known from the basement of the Pasha-Ladoga graben are rapakivi granites with 

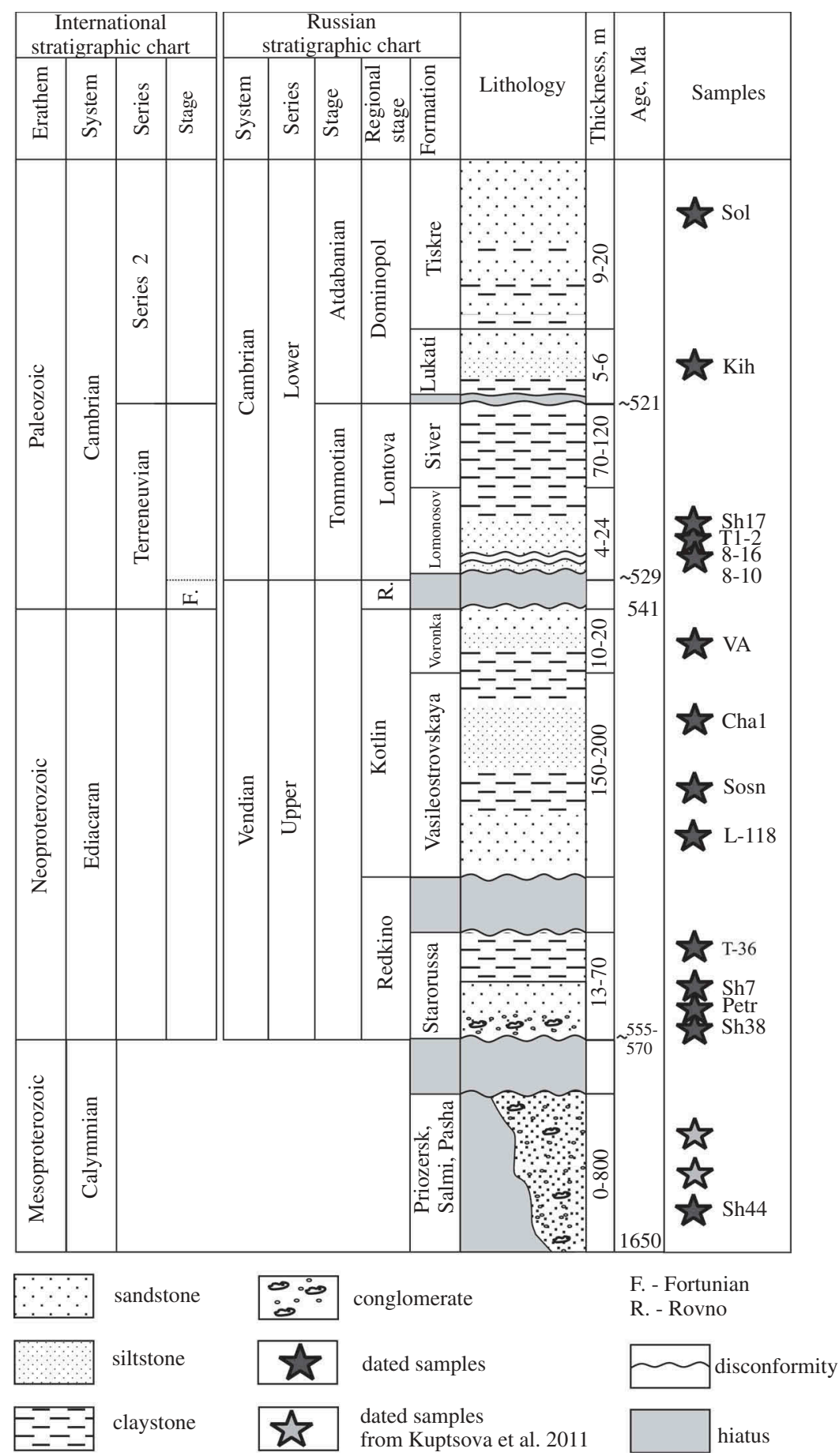

Figure 2. Simplified stratigraphic column with comparison of Russian and International stratigraphic subdivision and position of dated samples.

radiometric ages of 1547-1530 Ma (Amelin et al. 1997), whilst the sedimentary succession is intruded by mafic dykes and overlain by a sill with radiometric ages of $1457 \pm 2$ and $1459 \pm 3$ Ma respectively (U-Pb baddeleyite) (Rämö et al. 2001). These radiometric dates constrain the age of the oldest sedimentary succession overlying metamorphic basement as Early Mesoproterozoic. Since no sediments of Middle-Late Mesoproterozoic or Early-Middle Neoproterozoic age have been identified from the Leningrad region, either most of the study region represented a peneplain during this time (i.e., lack of sediment deposition), or sediments deposited during this time are not preserved due to later uplift and erosion.
The main phase of sedimentary cover started to form in the Late Ediacaran, when a marine transgression spread across most of the NW part of the East European Platform (Keller \& Rozanov 1980), resulting in deposition of the Starorussa, Vasileostrovskaya and Voronka formations. The oldest Ediacaran rocks unconformably overlie high-grade metamorphic basement and comprise the Starorussa Formation (Verbitskiy et al. 2012; Maksimov et al. 2015). The Starorussa Formation represents a transgressive sequence consisting of gravelly (mainly pebbly) conglomerates at the base, fining upward medium- to fine-grained sandstones, and topped by clays, with thickness increasing towards the southeast and ranging from 13 to $70 \mathrm{~m}$. 
The Vasileostrovskaya Formation disconformably overlies the Starorussa Formation in the west and conformably in east, but with angular unconformity overlies metamorphic basement in the north-western part of the Leningrad region (Verbitskiy et al. 2012; Maksimov et al. 2015). It consists of fine-grained sandstones and siltstones with thin layers of greenish-gray clays in the lower part of the succession. The upper part of the succession is represented by thin intercalations of siltstone and clay. The total thickness of the formation varies from 150 to $200 \mathrm{~m}$.

The Voronka Formation represents the youngest Ediacaran strata known from the study region and is preserved only to the west of Saint Petersburg, where it conformably overlies the Vasileostrovskaya Formation (Verbitskiy et al. 2012). It comprises thin-layered clays and siltstones containing sand grains at the base, grading upward to fine-grained sands and siltstones, with thickness varying from 10 to $20 \mathrm{~m}$.

Lower Cambrian deposits of the study region are represented by the Lomonosov, Siverskaya, Lukati and Tiskre formations. The Lomonosov Formation represents the oldest Cambrian succession described from the study region, disconformably overlying the Voronka Formation in the western part of the region and the Vasileostrovskaya Formation in the east (Verbitskiy et al. 2012; Maksimov et al. 2015). It comprises fine-grained sandstones and siltstones at the base, fining upward to intercalated clays and siltstones in the upper part of the succession, varying in thickness from 4 to $24 \mathrm{~m}$.

The overlying Siverskaya Formation is represented by a 70-120 m thick succession of clays, containing rare thin layers and lenses of siltstone (Verbitskiy et al. 2012; Maksimov et al. 2015).

The Lukati Formation lies disconformably on clays of the Siverskaya Formation and comprises 5-6 m of intercalating clays and siltstones, with subordinate beds of sandstone. The Tiskre Formation comprises mainly sandstones with subordinate layers of clay, with thickness ranging from 9 to $20 \mathrm{~m}$. Both the Lukati and Tiskre formations have been described only from the western part of the study region.

\section{Methodology}

Nine samples (Sol, Kih, 8-16, 8-10, VA, Cha1, Sosn, L118, T36, Petr) were analyzed for detrital zircon $\mathrm{U}-\mathrm{Pb}$ ages at the UTChron geochronology facility in the Department of Geological Sciences at the University of Texas, Austin. Samples underwent conventional heavy mineral separation and were grain mounted (no polishing) on one inch round epoxy pucks with double sided tape. All grains were depthprofiled using a Photon Machines Analyte G2 ATLex 300si ArF $193 \mathrm{~nm}$ Excimer Laser, equipped with a Helix twovolume ablation cell. The ablated aerosols were transported using $\mathrm{He}$ gas to, and analyzed with, a Thermo Fisher Element2 single collector, magnetic sector ICP mass spectrometer. Five samples (Sh7, Sh17, Sh38, Sh44, T1-2) were analyzed at the "Analytical center of mineralogical, geochemical and isotope Studies", Geological Institute, SB RAS Ulan-Ude, Russia, on a Thermo Scientific Element XR single collector sector-field ICP mass spectrometer using a UP-213 (New Wave Research) laser ablation system
(Khubanov et al. 2016). ${ }^{206} \mathrm{~Pb} /{ }^{238} \mathrm{U}$ ages are reported for ages younger than $1000 \mathrm{Ma}$ and ${ }^{207} \mathrm{~Pb} /{ }^{206} \mathrm{~Pb}$ ages for older ages. Following the approach proposed by Gehrels (2012), grains were considered discordant if there was greater than $30 \%$ discordance between the ${ }^{206} \mathrm{~Pb} /{ }^{238} \mathrm{U}$ age and the ${ }^{207} \mathrm{~Pb} /{ }^{235} \mathrm{U}$ age. The histograms and $\mathrm{KDE}$ (kernel density estimation) plots were produced using Density Plotter (Vermeesch 2012), with a bin width of $50 \mathrm{Ma}$ and the bandwidth of the relative frequency set to 20. Data tables are provided as Supplementary material.

\section{Results}

A total of 15 samples were analysed for detrital zircon $\mathrm{U}-\mathrm{Pb}$ ages. The samples were collected from both outcrops and wells, covering the Mesoproterozoic to Lower Cambrian stratigraphic interval (Figs. 2-4).

Sample Sh44 was collected from the oldest Mesoproterozoic sedimentary unit known across the study region, penetrated by the Shotkusa well. It contains zircons ranging from 2618 to $1208 \mathrm{Ma}$. The Archean grains are subordinate and do not form significant age peaks, while Paleoproterozoic and Early Mesoproterozoic grains are prevalent and group into three main peaks at ca. 1970, 1765, and $1565 \mathrm{Ma}$ (Fig. 3).

Samples Sh38, Sh7 and T36 were collected from clastic rocks of the Starorussa Formation, penetrated by the Shotkusa and Utkina Zavod' wells. Paleoproterozoic zircons prevail within these samples and form prominent peaks at ca. 2000, 1900-1950, and 1800-1850 Ma. Archean grains are abundant only in the Sh-38 sample and group into two main peaks at ca. 2670 and $2800 \mathrm{Ma}$ (Fig. 3). Mesoproterozoic grains form significant peaks at ca. 1600$1550 \mathrm{Ma}$ within all three samples, while zircons in sample Sh38 also form a peak at ca. 1485 Ma.

Samples Sosn, L118 and Petr (collected from engineering wells drilled for building construction) and Chal (collected from a natural outcrop) are from the Vasileostrovskaya Formation. Samples Sosn and L118 have a very similar distributions of detrital zircons, with the majority of Paleoproterozoic grains ranging in age between ca. 1880 and $1800 \mathrm{Ma}$. The youngest detrital zircons of sample Sosn group at ca 1600Ma, whilst within grains of L118 sample youngest grains form peak at ca $1585 \mathrm{Ma}$ (Fig. 3). Sample Petr shows a different distribution of detrital zircons, with the majority of Mesoproterozoic grains forming more less prominent peaks at ca. 1060, 1100, 1240, 1425, 1475, and $1540 \mathrm{Ma}$ Paleoproterozoic and Archean grains are subordinate and group at ca. 1875, 1980, and $2710 \mathrm{Ma}$.

Paleoproterozoic grains prevail within dated zircons from sample Cha1 and group at ca. 1640, 1700, 1870, 1930, and $1970 \mathrm{Ma}$. The Mesoproterozoic population forms peaks at ca. 1265 and $1520 \mathrm{Ma}$. The youngest zircon yielded an age of $626 \pm 6 \mathrm{Ma}$.

Sample VA was collected from sandstone of the Voronka Formation. The sample is dominated by Mesoproterozoic and Neoproterozoic zircons. Archean and Paleoproterozoic grains are subordinate and form minor peaks at ca. 2720, 2120 1895, 1855,1175 , and $1650 \mathrm{Ma}$. Mesoproterozoic grains form peaks at ca. $1575,1455,1240,1140$, and $1050 \mathrm{Ma}$, whilst Neoproterozoic zircons group at ca. 910, 705, 600, and $570 \mathrm{Ma}$ (Fig. 4). The 

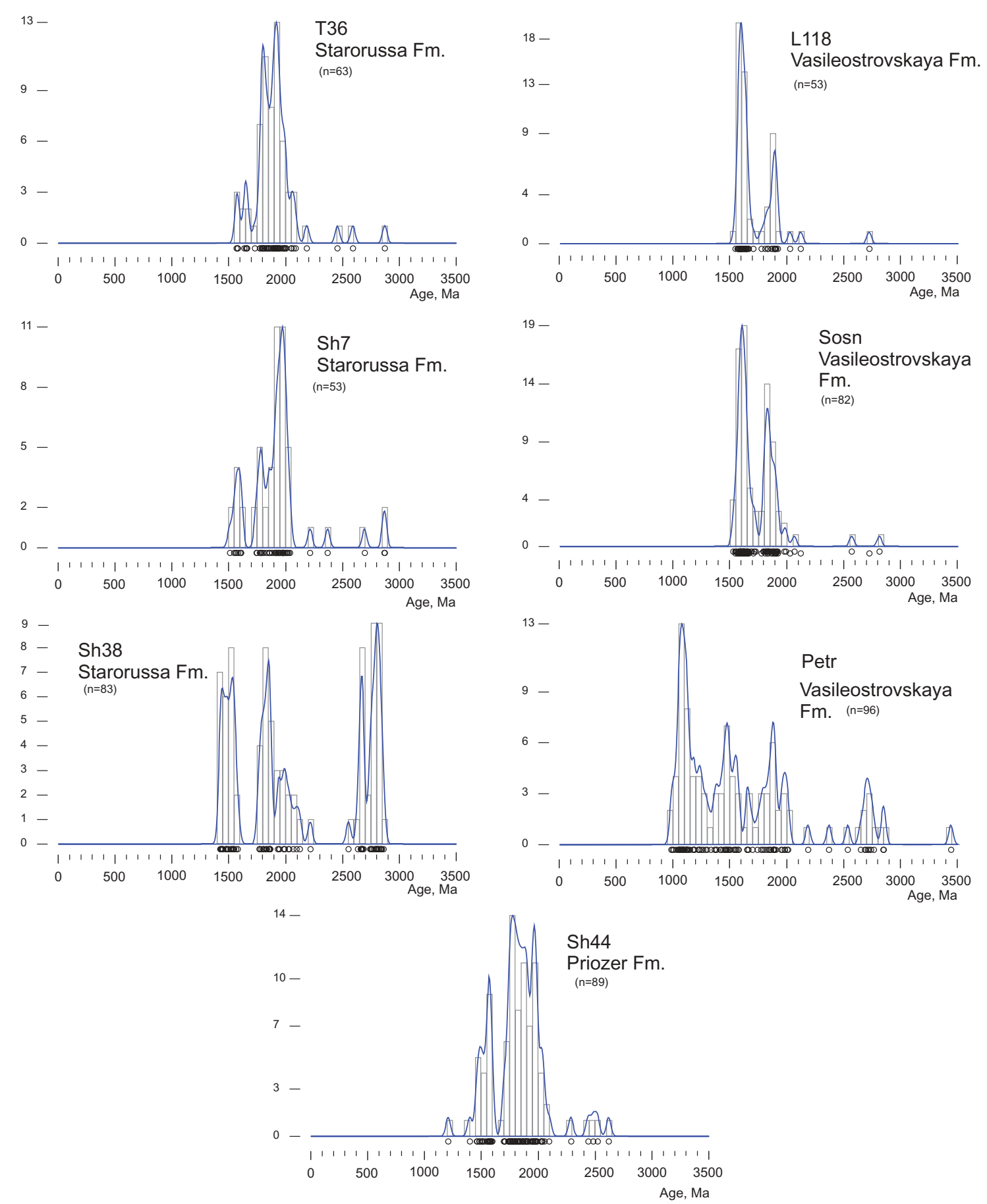

Figure 3. Histograms and KDE (kernel density estimation, Vermeesch 2012) plots depicting the U-Pb detrital zircon data from Mesoproterozoic-Ediacaran samples analyzed in this study, with group 1 (Sh44 sample) and group 2 (Sh38, Sh7, T36, Petr, Sosn, L118) of studied samples (see text for discussion).

weighted average age of the three youngest grains is $554 \pm 5 \mathrm{Ma}$, approximating the latest Ediacaran depositional age of the Voronka Formation.

Samples T1-2, Sh17, 8-10 and 8-6 were collected from the Lomonosov Formation. Archean grains are subordinate and do not form significant peaks. Paleoproterozoic zircons group at ca. $1800,1900 \mathrm{Ma}$ and 2050 within dated grains of 8-10 \& 8-6 samples. Paleoproterozoic grains from T1-2 and Sh17 samples do not from significant peaks. The majority of the dated grains are Meso- and Neoproterozoic in age. All samples have a prominent detrital zircons population at ca
1450-1550 Ma in age, with subordinate group is $1200-1250 \mathrm{Ma}$ in age. The majority of Neoproterozoic grains group at ca $900-950 \mathrm{Ma}$ and 580-550 Ma (Fig. 4). The youngest grains are Cambrian in age and close to age of sedimentation.

Samples Kih (Lukati Formation) and Sol (Tiskre Formation) have similar distributions of detrital zircons, with the majority of dated grains yielding Mesoproterozoic ages. Archean and Paleoproterozoic grains are subordinate and form small peaks falling in the age range ca. 2700-2750, 2000-2100, 1900-1600 Ma (Fig. 4). The numerous Mesoproterozoic grains group at ca. 


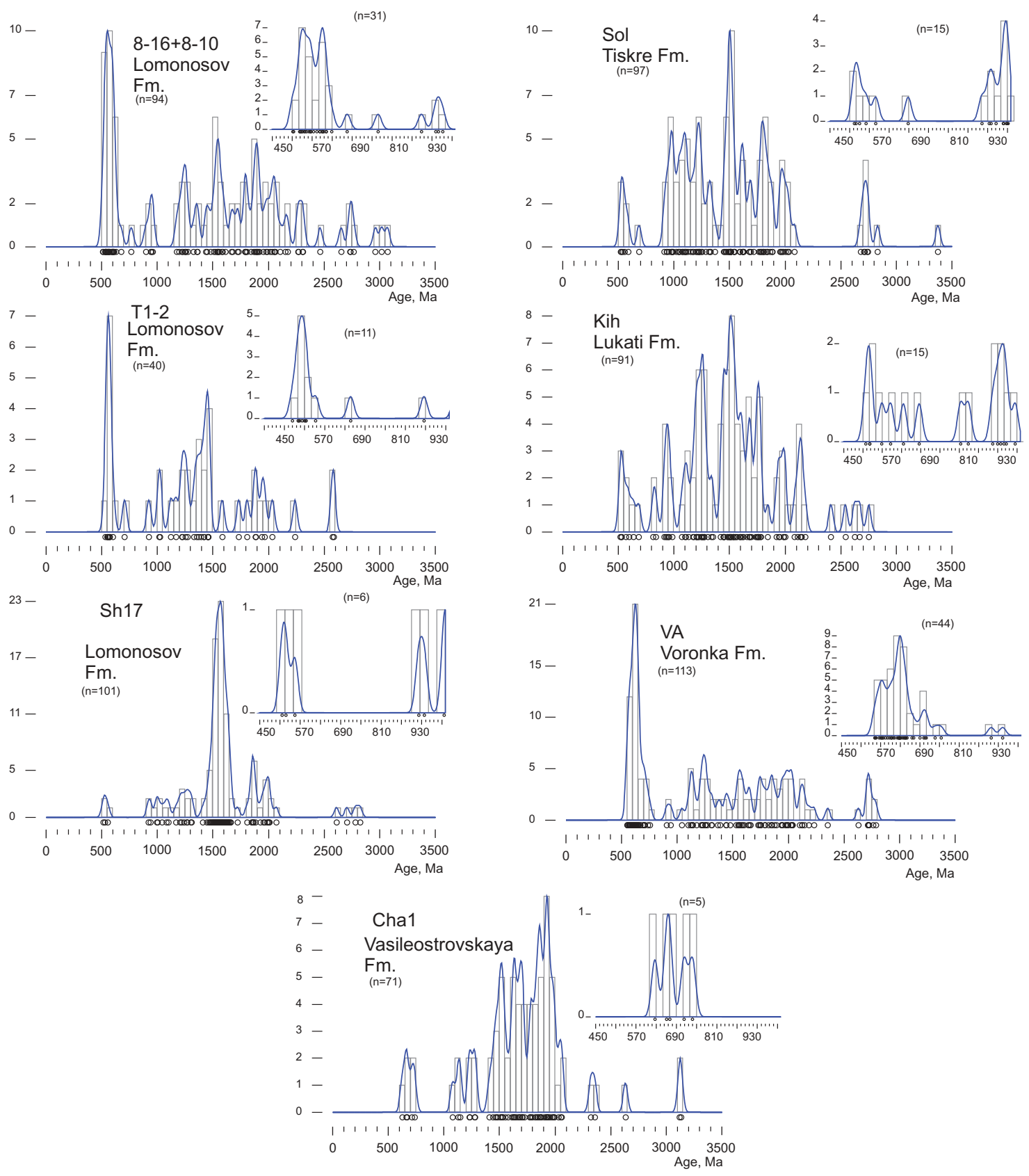

Figure 4. Histograms and KDE (kernel density estimation, Vermeesch 2012) plots depicting the U-Pb detrital zircon data from Upper Vendian-Lower Cambrian samples analyzed in this study, with group 3 of studied samples (see text for discussion). The primary KDE plots show the full age range of the samples, and the secondary pullouts depict ages from 450 to $1000 \mathrm{Ma}$.

1100-1080, 1200-1260, 1450, and 1500-1550 Ma. The Neoproterozoic grains group at ca. 950 whilst Cambrian grains form peaks at ca. $530-535 \mathrm{Ma}$.

\section{Discussion}

Our detrital zircon results from the Mesoproterozoic to Lower Cambrian strata of NW Russia provide new geological constraints on the Mesoproterozoic - Early Cambrian paleogeography of the north-western part of the East European Platform.

The dated samples can be divided into three main groups based on the ages of detrital zircons. The first group is represented by the oldest Mesoproterozoic sample (Sh44) collected from the southern part of the Pasha-Ladoga graben, and exhibits a similar detrital zircon age distribution to clastic sedimentary rocks in the northern part of the graben (Kuptsova et al. 2011). Our data are in agreement with the data of Kuptsova et al. (2011), who also identified a prevalence of late Paleoproterozoic - earliest Mesoproterozoic zircons (1500-1900 Ma) in Mesoproterozoic sedimentary rocks of the Pasha-Ladoga graben (Fig. 5). Rocks of this age range are widespread across the neighbouring part of Fennoscandia (Bogdanova et al. 2008), with grains dated as 1550-1530 Ma corresponding to the age of the Salmi Massif, located in close proximity to the Pasha-Ladoga graben (Amelin et al. 1997) (Fig. 6). Therefore, our detrital zircon data from the Mesoproterozoic clastic rocks of the Pasha-Ladoga graben support a source from weathering of a proximal source region. 
After a long period of erosion and/or non-deposition, clastic sedimentation commenced more widely across the study area in the Late Ediacaran (Late Vendian) and continued with short hiatuses throughout the Early Paleozoic (Keller \& Rozanov 1980). The six dated samples from the Upper Ediacaran strata (Sh38, Sh7, and T36 from the Starorussa Formation; Sosn, L118, and Petr from the Vasileostrovskaya Formation) are characterized by a similar distribution of detrital zircon ages, with major populations of zircons ranging in age between 2000-1850 and 1600-1550 Ma. Archean grains are only abundant in sample Sh38 , with peaks at 2800 and $2670 \mathrm{Ma}$, corresponding to the ages of accretionary events culminating in formation of the FennoKarelian protocontinent (Bogdanova et al. 2008). Numerous Late Paleoproterozoic zircons (1950-1850 Ma) reported from all samples correlate with the ages of several episodes of accretion reported from southwestern Fennoscandia and referred to as the Svecofennian Orogeny (Nironen 1997; Lahtinen et al. 2005; Korja et al. 2006; Bogdanova et al. 2008). The next prominent zircon population ranges in age from $1600-1550 \mathrm{Ma}$, correlating with rapakivi granite igneous activity in the interior parts of Fennoscandia (Amelin et al. 1997; Bogdanova et al. 2008; Rämö et al. 2014). Latest Mesoproterozoic zircons are only observed from sample Petr and exhibit similar ages to magmatic events described from the Sveconorwegian Orogen (Bingen et al. 2008; Roberts \& Slagstad 2015).

Moreover, our distribution of detrital zircon ages is comparable to those reported from strata of the Kotlin Regional Stage (Late Ediacaran) to the west of the study area in central Estonia (Isozaki et al. 2014) (Fig. 5). Dated samples from the
Starorussa and Vasileostrovskaya formations are generally dominated by detrital zircons that are much older than the depositional ages of the formations. Therefore, in combination with data from central Estonia (Isozaki et al. 2014), our data suggest that clastic detritus deposited across much of the Late Ediacaran sedimentary basin, which occupies present-day NW Russia and Estonia, was mainly sourced from the southwestern part of the Baltic Shield (in modern coordinates).

The third group of samples includes Chal (uppermost part of the Vasileostrovskaya Formation) and VA (Voronka Formation) from the Upper Ediacaran strata, and Sh17, T12, 8-16 and 8-10 (Lomonosov Formation), Kih (Lukati Formation), and Sol (Tiskre Formation) from Lower Cambrian deposits, which have strikingly similar detrital zircon age distributions. These deposits have a broad distribution of detrital zircons, with ages ranging from 2800 to $530 \mathrm{Ma}$. Neoarchean grains (ca. 2700-2500 Ma) correlate with ages of accretionary events known from the FennoKarelian area (Bogdanova et al. 2008). Zircon ages of ca. 1950-1800 Ma could be correlated with magmatic events within the Svecofennian Orogen and also with rocks of these ages reported from the Kola-Karelia province (Korja et al. 2006). The majority of the latest Paleoproterozoic zircons fall within the 1800-1600 Ma age range and can be correlated with formation of the Transscandinavian Igneous Belt (Larson \& Berglund 1992; Andersson et al. 2004; Gorbatschev 2004). Zircon populations of ca. 1600-1500 Ma, 1300-1200, and 1100-950 Ma compare closely with characteristic ages within the Sveconorwegian Orogen, including

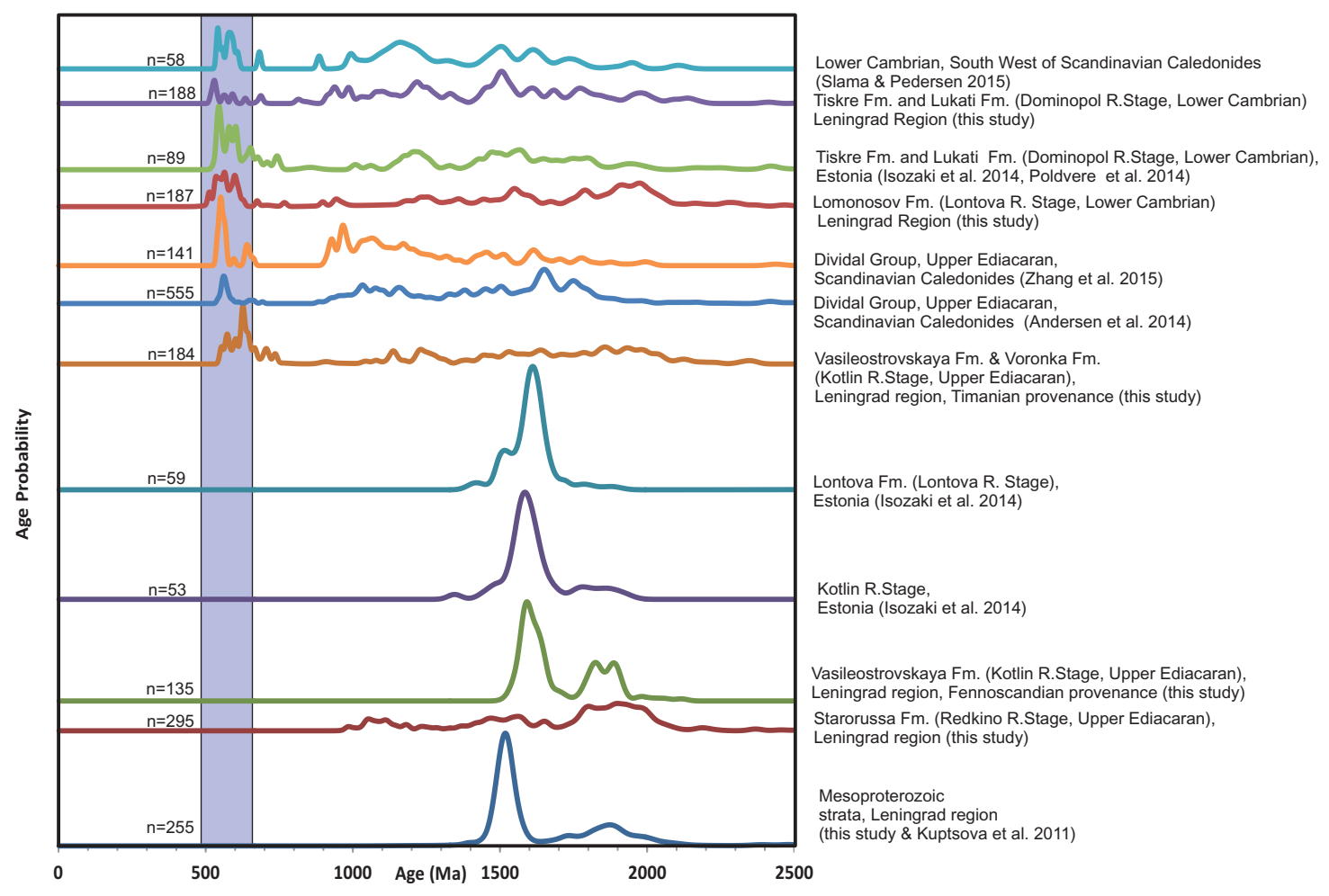

Figure 5. Comparison of detrital zircon age spectra (KDE plots) of Upper Ediacaran-Lower Cambrian rocks from the NW part of the East European Platform. Blue shaded area marks the timing of the Timanian orogeny. 

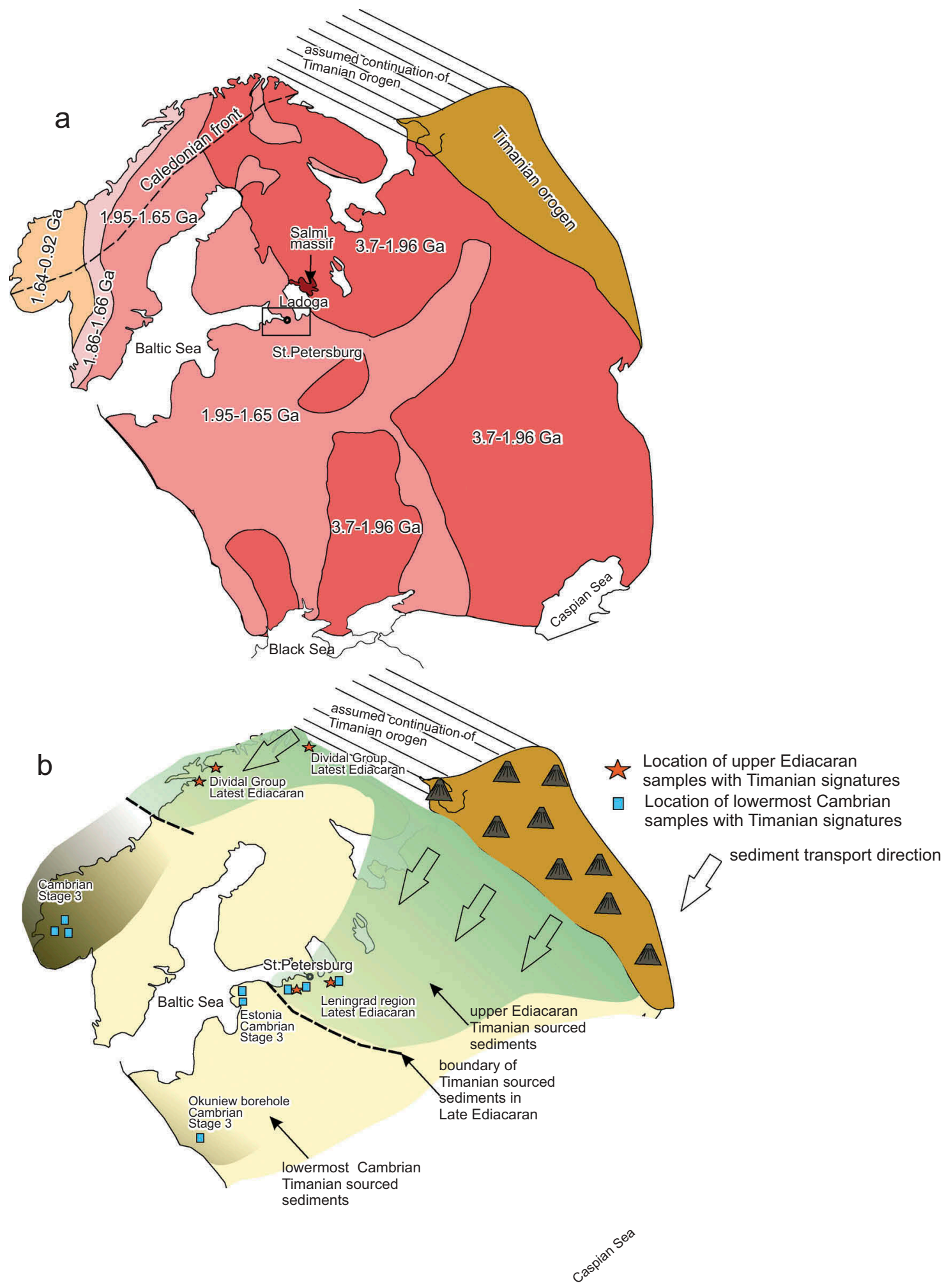

Black Sea

Figure 6. A. Sketch map of the main crustal domains of the East European Platform (modified from Bogdanova et al. 2008; Andresen et al. 2014). B. Sketch map of northern Baltica showing the localities where Upper Ediacaran to Lower Cambrian detrital zircons with probable Timanian provenance were reported (data from Andresen et al. 2014; Isozaki et al. 2014; Poldvere et al. 2014; Slama \& Pedersen 2015; this study).

both basement terranes and the ages of orogenic episodes (Bingen et al. 2008). One characteristic feature of the third group of samples is the presence of detrital zircons with ages close to the depositional age of the formation during the latest Neoproterozoic to earliest Cambrian (ca. 650-525 Ma). Felsic rocks of these ages are not known from the basement of the 
East European platform, however, coeval magmatic and metamorphic events in this age range are reported from the Timanian Orogen (Gee et al. 2000; Pease et al. 2004; Kuznetsov et al. 2007) located along the north-eastern margin of the East European Craton (in present-day coordinates). Moreover, sedimentary rocks with the youngest zircons ages close to depositional ages are characteristic of foreland basin settings, located adjacent to a rising mountain range and proximal source of clastic detritus (Cawood et al. 2012). We suggest that the Paleoproterozoic and Mesoproterozoic detrital zircons from the uppermost Ediacaran-lowermost Cambrian deposits of the Leningrad region (group three of dated samples) also originated from the Timanides, due to the presence of zircons of comparable ages reported from Mesoproterozoic rocks of the Timan Ridge (Kuznetsov et al. 2010; Brusnitsyna et al. 2018).

Furthermore, a review of available detrital zircon ages from coeval Upper Ediacaran - Lower Cambrian strata (Fig. 5) of the north-western part of the East European Craton reveals a strong similarity between detrital zircon signatures. Our new data suggest that input of clastics from the Timanian Orogen started in the Late Ediacaran (Kotlin regional stage), contradicting previous claims that the onset of deposition of Timanian-derived detritus across major parts of Baltica is approximately coeval with the boundary between the Cambrian Stage 2 and Stage 3 (ca. 521 Ma; Slama \& Pedersen 2015; Slama 2016) (Fig. 6). Our data suggest that continent-scale sediment transport across the East European Craton carrying detritus from the Timanian Orogen began during the Late Ediacaran. Detrital zircon data from the Dividal Group of the Scandinavian Caledonides (Andresen et al. 2014; Zhang et al. 2015) have also been interpreted to show that Timanian sourced detritus appeared on the Baltican margin in the Latest Ediacaran.

\section{Conclusions}

The results presented in this study provide new constraints on the paleogeographic evolution of the Baltica paleocontinent. The dated samples can be divided into three groups based on the ages of detrital zircons. The first group represents the Lower Mesoproterozoic rocks of the Pasha-Ladoga basin. Detrital zircon data suggest derivation of clastic detritus from the neighboring crystalline basement comprising predominantly rapakivi granite. The second group includes Upper Ediacaran samples containing populations of detrital zircons with ages in the range of ca. 2800-2670, 2000-1850, and 1600-1550 Ma, suggesting a source from the southwestern part of the Baltic Shield for most of the Late Ediacaran sedimentary basin located in the interior part of Baltica. The third group of samples, collected both from the uppermost Ediacaran and lowermost Cambrian deposits, contains Late Neoproterozoic-earliest Cambrian zircons which are diagnostic of a Timanian source area and show similar age spectra to those reported earlier from coeval rocks of the Scandinavian Caledonides. Therefore, we conclude that erosion and transport of continental detritus from the Timanian Orogen began during the Late Ediacaran, earlier than previously supposed, with transport of Timanian detritus to not only the marginal part (Scandinavian Caledonides) but also the interior part of Baltica.

\section{Acknowledgments}

Thanks to the UTChron geoanalytical staff and the University of Texas at Austin for laboratory support. Reviews by Dr. Stefan Claesson, Dr. Jiri Slama and Dr. Guido Meinhold greatly improved the initial manuscript. We are grateful to Dr. James Barnet for useful comments on the first draft of the paper and correcting the English.

\section{Disclosure statement}

No potential conflict of interest was reported by the authors.

\section{Funding}

This research was supported by RFBR grant 17-05-00858 and №18-3500407, RCN project- Changes at the Top of the World through Volcanism and Plate Tectonics: A Norwegian-Russian-North American collaboration in Arctic research and education: NOR-R-AM (no. 261729). V.P. supported from the project №0153-2019-0003 Russian Academy of Science.RCN [project- Changes at the Top of the World through V].

\section{ORCID}

P.V. Fedorov (iD http://orcid.org/0000-0002-9888-1381

\section{References}

Amelin, Y.A., Larin, A.M., \& Tucker, R.D., 1997: Chronology of multiphase emplacement of the Salmi Rapakivi granite anorthosite complex, Baltic shield: implications for magmatic evolution. Contributions to Mineralogy and Petrology 127, 353-368. doi:10.1007/ s004100050285

Andersson, U. B., Sjöström, H., Högdahl, K. H. O. \& Eklund, O., 2004: The Transscandinavian Igneous Belt, evolutionary models. In The Transscandinavian Igneous Belt (TIB) in Sweden: A Review of its Character and Evolution (Högdahl K., Andersson U. B. (eds)). Geological Survey of Finland, Special Paper 37, Espoo, 104-12.

Andresen, A., Agyei-Dwarko, N.Y., Kristoffersen, M., \& Hanken, N.-M., 2014: A Timanian foreland basin setting for the late Neoproterozoic-Early Palaeozoic cover sequences (Dividal Group) of northeastern Baltica. Geological Society London Special Publications 390,f 157-175. doi:10.1144/SP390.29

Bingen, B., Nordgulen, Ø., \& Viola, G.A., 2008: Four-phase model for the sveconorwegian orogeny, SW Scandinavia. Norsk Geologisk Tidsskrift 88(1), 43-72.

Bogdanova, S.V., Bingen, B., Gorbatschev, R., Kheraskova, T.N., Kozlov, V.I., Puchkov, V.N., \& Volozh, Y.A., 2008: The East European Craton (Baltica) before and during the assembly of Rodinia. Precambrian Research 160(1-2), 23-45. doi:10.1016/j. precamres.2007.04.024

Brusnitsyna, E.A., Ershova, V.B., Khudoley, A.K., \& Andersen, T., 2018: Age and provenance of the Mesoproterozoic-Lower Neoproterozoic strata of the Chetlass Stone (Timan Range): constraints from $U-P b$ detrital zircon study. Abstract book ICAM 2018, Stockholm, Sweden.

Cawood, P.A., Hawkesworth, C., \& Dhuime, B., 2012: Detrital zircon record and tectonic setting. Geology 40, 875-878. doi:10.1130/ G32945.1

Gee, D.G., Andréasson, P.-G., Lorenz, H., Frei, D., \& Majka, J., 2015: Detrital zircon signatures of the Baltoscandian margin along the arctic circle caledonides in Sweden: the Sveconorwegian connection. Precambrian Research 265, 40-56. doi:10.1016/j.precamres.2015.05.012 
Gee, D.G., Beliakova, L., Pease, V., Larionov, A., \& Dovshikova, L., 2000: New, single zircon ( $\mathrm{Pb}$-evaporation) ages from Vendian intrusions in the basement beneath the Pechora Basin, northeastern Baltica. Polarforschung,Bremerhaven, Alfred Wegener Institute for Polar and Marine Research \& German Society of Polar Research 68, 161-170.

Gee, D.G., Ladenberger, A., Dahlqvist, P., Majka, J., Be'Eri-Shlevin, Y., Frei, D., \& Thomsen, T., 2014: The Baltoscandian margin detrital zircon signatures of the central scandes. Geological Society Special Publication 390(1), 131-155. doi:10.1144/SP390.20

Gehrels, G., 2012: Detrital zircon U-Pb geochronology: current methods and new opportunities. In C. Busby \& A. Azor (eds.): Tectonics of sedimentary basins: recent advances, chapter 2, 47-62. Blackwell Publishing Ltd., Chichester, UK.

Gorbatschev, R., 2004: The Transscandinavian Igneous Belt - introduction and background. In The Transscandinavian Igneous Belt (TIB) in Sweden: A Review of its Character and Evolution (Högdahl K., Andersson U. B. (eds)). Geological Survey of Finland, Special Paper 37, Espoo, 9-15.

Isozaki, Y., Poldvere, A., Bauert, H., Nakahata, H., Aokia, K., Sakata, S., \& Hirata, T., 2014: Provenance shift in Cambrian mid-Baltica: detrital zircon chronology of Ediacaran-Cambrian sandstones in Estonia. Estonian Journal of Earth Sciences 63, 251-256. doi:10.3176/earth.2014.27

Ivleva, A.S., Podkovyrov, V.N., Ershova, V.B., Anfinson, O.A., Khudoley, A.K., Fedorov, P.V., Maslov, A.V., \& Zdobin, D.Y., 2016: Results of U-pb LA-ICP-MS dating of detrital zircons from Ediacaran-early Cambrian deposits of the eastern part of the Baltic monoclise. Doklady Earth Sciences 468(2), 593-597. doi:10.1134/ S1028334X16060064

Ivleva, A.S., Podkovyrov, V.N., Ershova, V.B., Khubanov, V.B., Khudoley, A.K., Sychev, S.N., Vdovina, N.I., \& Maslov, A.V., 2018: U-pb LA-ICP-MS age of detrital zircons from the Lower Riphean and Upper Vendian deposits of the Luga-ladoga Monocline. Doklady Earth Sciences 480(2), 695-699. doi:10.1134/S1028334X1806003X

Keller, B.M. \& Rozanov, Y., 1980: Paleogeography and lithology of Vendian and Cambrian of western part of the East-European platform, 113. NaukaMoscow.

Khubanov, V.B., Buyantuev, M.D., \& Tsygankov, A.A., 2016: U-Pb dating of zircons from PZ3-MZ igneous complexes of Transbaikalia by sector-field mass spectrometry with laser sampling: technique and comparison with SHRIMP. Russian Geology and Geophysics 57(1), 190-205. doi:10.1016/j.rgg.2016.01.013

Korja, A., Lahtinen, R., \& Nironen, M., 2006: The Svecofennian orogen: A collage of microcontinents and island arcs. Geological Society Memoir 32, 561-578. doi:10.1144/GSL.MEM.2006.032.01.34

Kuptsova, A.V., Khudoley, A.K., Davis, W., Rainbird, R.H., Kovach, V. P., \& Zagornaya, N.Y., 2011: Age and provenances of sandstones from the Riphean Priozersk and Salmi formations in the eastern Pasha-Ladoga basin (southern margin of the Baltic Shield). Stratigraphy and Geological Correlation 19(2), 125-140. doi:10.1134/ S0869593811020067

Kuznetsov, N.B., Natapov, L.M., Belousova, E.A., O’Reilly, S.Y., \& Griffin, W.L., 2010: Geochronological, geochemical and isotopic study of detrital zircon suites from late Neoproterozoic clastic strata along the NE Margin of the East European Craton: implications for plate tectonic models. Gondwana Research 17, 583-601. doi:10.1016/j. gr.2009.08.005

Kuznetsov, N.B., Soboleva, A.A., Udoratina, O.V., Hertseva, M.V., \& Andrelchev, V., 2007: Pre-Ordovician tectonic evolution and volcano-plutonic associations of the Timanides and northern Pre-
Uralides, northeast part of the East European Craton. Gondwana Research 12, 305-323. doi:10.1016/j.gr.2006.10.021

Lahtinen, R., Korja, A., \& Nironen, M., 2005: Paleoproterozoic tectonic evolution. In M. Lehtinen, P.A. Nurmi, \& O.T. Ramo (eds.): Precambrian geology of Finland-key to the evolution of the Fennoscandian Shield, 481-532. Elsevier, Amsterdam.

Larson, S.Å. \& Berglund, J., 1992: A chronological subdivision of the Transscandinavian Igneous Belt - three magmatic episodes? GFF $115,459-461$.

Maksimov, A.V., Bogdanov, Y.B., Voinova, O.A., \& Kossovaya, O.L., 2015: State geological map of Russia, Scale 1:1000 000, P35-O36, explanatory note, VSEGEI. (in Russian) Saint Petersburg.

Miller, E.L., Kuznetsov, N., Soboleva, A., Udoratina, O., Grove, M.J., \& Gehrels, G., 2011: Baltica in the Cordillera? Geology 39(8), 791-794. doi:10.1130/G31910.1

Nironen, M., 1997: The Svecofennian orogen: a tectonic model. Precambrian Research 86, 21-44. doi:10.1016/S0301-9268(97)00039-9

Pease, V., Dovzghikova, E., Beliakova, L., \& Gee, D.G., 2004: Late Neoproterozoic granitoid magmatism in the basement to the Pechora Basin, NW Russia: geochemical constraints indicate westward subduction beneath NE Baltica. In D.G. Gee \& V. Pease (eds.): The Neoproterozoic Timanide Orogen of Eastern Baltica, Memoirs 30. 75-85. Geological Society, London.

Poldvere, A., Isozaki, Y., Bauert, H., Kirs, J., Aoki, K., Sakata, S., \& Hirata, T., 2014: Detrital zircon ages of Cambrian and Devonian sandstones from Estonia, central Baltica: a possible link to Avalonia during the Late Neoproterozoic. GFF 136, 214-217. doi:10.1080/ 11035897.2013.873986

Rämö, O.T., Mänttäri, I., Vaasjoki, U.B.G.J., \& Sviridenko, L.P., 2001: Age and Significance of Mesoproterozoic CFB Magmatism, Lake Ladoga Region, NW. Russia. In: GSA Annual Meeting. Petrology I, Session 57, A139, Massachusetts, Boston.

Rämö, O.T., Turkki, V., Mänttäri, I., Heinonen, A., Larjamo, K.L., \& Ahaye, Y., 2014: Age and isotopic fingerprints of some plutonic rocks in the wiborg rapakivi granite batholith with special reference to the dark wiborgite of the ristisaari Island. Bulletin of the Geological Society of Finland 86(2), 71-91. doi:10.17741/bgsf/86.2.002

Roberts, N.M.W. \& Slagstad, T., 2015: Continental growth and reworking on the edge of the Columbia and Rodinia supercontinents; 1.86-0.9 Ga accretionary orogeny in southwest Fennoscandia (2015). International Geology Review 57(11-12), 1582-1606. doi:10.1080/ 00206814.2014.958579

Slama, J., 2016: Rare late Neoproterozoic detritus in SW Scandinavia as a response to distant tectonic processes. Terra Nova 28(6), 394-401. doi:10.1111/ter.2016.28.issue-6

Slama, J. \& Pedersen, R.B., 2015: Zircon provenance of SW caledonian phyllites reveals a distant timanian sediment source. Journal of the Geological Society 172(4), 465-478. doi:10.1144/jgs2014-143

Verbitskiy, V.R., Verbitskiy, I.V., Vasil'eva, O.V., \& Savanin, V.V., 2012: State geological map of Russia, Scale 1:1000 000, O35-O36, explanatory note, VSEGEI, Saint Petersburg. (in Russian).

Vermeesch, P., 2012: On the visualisation of detrital age distributions. Chemical Geology 312-313, 190-194. doi:10.1016/j. chemgeo.2012.04.021

Zhang, W., Roberts, D., \& Pease, V., 2015: Provenance characteristics and regional implications of Neoproterozoic, Timanian-margin successions and a basal Caledonian nappe in northern Norway. Precambrian Research 268, 153-167. doi:10.1016/j. precamres.2015.07.006 